\author{
COSTANZA JUCKER $^{1 *}$ - AUGUSTO LONI ${ }^{2}$ - MATTIA CALZOLARI ${ }^{3}$ - SERGEY BELOKOBYLSKIJ ${ }^{4,5}$ \\ DANIELA LUPI ${ }^{1}$
}

\title{
ACCIDENTAL INTRODUCTION IN ITALY OF THE PARASITOID SPATHIUS VULNIFICUS WILKINSON (HYMENOPTERA BRACONIDAE DORYCTINAE)
}

\author{
(1) DeFENS - Department of Food, Environmental and Nutritional Sciences, University of Milan, Italy. \\ ${ }^{(}{ }^{2}$ Department of Agriculture, Food and Environment, Pisa University, Italy. \\ ( $)$ IZSLER - Istituto Zooprofilattico Sperimentale della Lombardia e dell'Emilia Romagna "Bruno Ubertini”, Reggio \\ Emilia, Italy. \\ $\left({ }^{4}\right)$ Zoological Institute of the Russian Academy of Sciences, St. Petersburg, Russia. \\ (5) Museum and Institute of Zoology, Polish Academy of Sciences, Warszawa, Poland. \\ Corresponding author (e-mail: costanza.jucker@unimi.it).
}

Jucker C., Loni A., Calzolari M., Belokobylskij S., Lupi D. - Accidental introduction in Italy of the parasitoid Spathius vulnificus Wilkinson (Hymenoptera Braconidae Doryctinae).

This paper reports the finding of the Hymenoptera Doryctinae Spathius vulnificus Wilkinson for the first time in Europe. This is an idiobiont ectoparasitoid attacking woodborer larvae of some Bostrichidae (Coleoptera) species. Such exotic parasitoid, mainly spread in the Oriental and southeastern part of the Palaeartic Region, has been intercepted in association with the lesser auger beetle Heterobostrychus aequalis (Waterhouse) (Coleoptera, Bostrichidae), imported from the Asian Far East in wood packaging material. This report represents an updating on the worldwide distribution of the parasitoid.

KEY WoRDS: biological control, exotic species, new invasion, parasitoid.

\section{INTRODUCTION}

Expanding international trade, together with global warming and tourism, have been responsible for the unintentional introduction of many exotic insect pests and diseases, threatening native biological diversity and causing economic losses (PIMENTEl et al., 2005; JUCKER \& LUPI, 2011; LuPI et al., 2013; BRADSHAW et al., 2016). Numerous examples of introduced species (often pests) have become extremely invasive and caused serious environmental and economic damages to different biocenosis (ROQUES et al., 2009; BRADSHAW et al., 2016). The worldwide increase of trade in goods is mainly related with the use of solid wood packaging material (SWPM). However, wood for the construction of pallets can easily be infested by woodboring beetles, and represent a pathway for their spread that augments the frequency of new introductions (HuMBLE, 2010; Roques, 2010). In the recent years, different xylophagous have been detected and established in new habitat thanks to SWPM. Some examples include the emerald ash borer (Agrilus planipennis Fairmaire) (PoLAND \& McCullough, 2006; BARANChiKov et al., 2008), and the Asian long-horned beetle (Anoplophora glabripennis (Motschulsky) (MACLEOD et al., 2002; MASPERO et al., 2007; FACCOLI et al., 2015).

Many quarantine and inspection services act in a widescale aiming to limit the movement of invading pests, nevertheless introduction of exotic insects and pathogens remains an awkwardly challenge to manage. In particular, wood-boring insects have long-living preimaginal instars, making them extremely suited to survive long periods within dry wood along all the transport duration. Moreover, preimmaginal instars live hidden inside the wood, making them more difficult to detect. Due to numerous introductions of invasive xylophagous insects and other orga- nisms in many Countries, International Standards for Phytosanitary Measures No. 15 (ISPM15) were developed in 2002 by the International Plant Protection Convention (IPPC) aiming to harmonize international regulations and phytosanitary treatments for SWPM used for trade.

Even if the main attention of inspection services focuses on insect pests, the finding of exotic parasitod insects that can be accidentally introduced with their host is not rare (Berry \& Walker, 2004; KaufMan \& Wright, 2009). This is particularly permissible when the natural enemy is a concealed species, such as an endoparasitoid, or an ectoparasitoid living in hidden galleries excavated by larvae of wood boring insects (LONI et al., 2012; LONI et al., 2015).

In this paper we report the first detection of Spathius vulnificus Wilkinson (Hymenoptera Braconidae Doryctinae) in Italy, emerged from larvae of the lesser auger beetle, Heterobostrychus aequalis (Waterhouse, 1884) (Coleoptera, Bostrichidae).

\section{MATERIAL AND METHODS}

Four adults of a braconid wasp were detected in August 2017 in Medolla (MO), northern Italy $\left(44^{\circ} 84^{\prime} 85^{\prime \prime} \mathrm{N}\right.$; $11^{\circ} 07^{\prime} 09^{\prime}$ 'E), in a factory importing goods from the far South of the Far East Asia. Samples were collected and the wasps were identified using the keys of WILKINSON (1931) and Nixon (1943). After this detection, an accurate monitoring in the same area has allowed the discovery of some wood packaging materials used to transport goods from Malaysia with evident signs of a massive infestation by xylophagous insects. Many exit holes due to xylophagous were observed and different life instars of the Coleoptera were collected, both alive and dead. Insects were between the stretch film and the cardboard that 
constitutes the boxes, and between the boxes themselves. Also these beetles have been sampled and classified.

\section{RESULTS AND DISCUSSION}

The collected females of parasitoids belonged to the braconid Spathius vulnificus Wilkinson, 1931 (Hymenoptera Braconidae). The xylophagous insects emerged from the infested wood material were all identified as Heterobostrychus aequalis (Waterhouse, 1884), (Coleoptera Bostrichidae), commonly known as the lesser auger beetle. This beetle species actively infests timber and wood products, especially if dry, and completes its entire cycle in these substrates. H. aequalis is native to the South East Asia, and it was intercepted in Italy and other European countries between 1987 and 2007, but was never established (AzMI et al., 2011). This is the first record of $S$. vulnificus on the host $H$. aequalis in Italy and Europe.

Spathius Nees, 1818 is the largest genus in subfamily Doryctinae (Hymenoptera Braconidae). To date, more than 450 species are known in this genus (ZALDIVAR-RIVERON et al., 2018), mainly widespread in the Oriental Region as well as in the Afrotropical and southeastern part of the Palaearctic Regions (BELOKOBYLSKIJ, 2003, 2009; BeloKOBYLSKIJ \& MAETO, 2009; TANG et al., 2015; Yu et al., 2016). As far as known, all species of Spathius are idiobiont ectoparasitoids of concealed woodborer Coleoptera larvae from the families Anobiidae, Bostrichidae, Buprestidae, Cerambycidae and Curculionidae (including Scolytinae) (Shenefelt \& Marsh, 1976; BelokobylskiJ, 1996a; 1996b; 2003; BeloKobylskis \& MAeto, 2009; Yu et al., 2016). However, some Spathius species were also found parasitizing lepidopteran larvae living in stems or wood, belonging to the families Sesiidae, Pyralidae, and Tortricidae, and also Hymenoptera larvae of the family Xiphydriidae (BELOKOBYLSKIJ, 2003).

Spathius vulnificus Wilkinson, 1931 (Fig. I, 1-8) was originally described from India (WILKINSON, 1931). NIXON (1943) in his World revision of this genus created the $S$. vulnificus species group together with Oriental $S$. critolaus Nixon, 1943 and S. sul Nixon, 1941; later S. paracritolaus Belokobylskij, 1996 described from Taiwan, was additionally added into this group (BELOKOBYLSKIJ, 1996a). The peculiar morphological distinguishing feature of this and related groups ( $S$. ocyroe Nixon, $S$. rusticulus Wilkinson and $S$. urios Nixon; the last group was later united with the previous one: BeloKobylskiJ \& MAETO, 2009) is the "face having a satiny sheen due to a sculpture of excessively fine, absolutely even, transverse aciculation, like the surface of a gramophone record" (NIXON, 1943). Morphologically S. vulnificus is closely related to $S$. critolaus. In latter species the great majority of the specimens are micropterous forms while $S$. vulnificus as far as known has only macropterous (full-winged) forms. In case of macropterous specimens these two species can be easily distinguished for the coloration and sculpture of the second and third tergites surface; although reliable, this character can be rather variable in large series of specimens (NIXON, 1943). Other secondary features available for discrimination of these taxa are the length of the ovipositor sheet (shorter in S. critolaus) and the length of the second abscissa of radius (which is less the half of the third one in $S$. vulnificus and about two thirds in S. critolaus).

In nature in India, $S$. vulnificus has been commonly found parasitizing larvae of Dinoderus brevis Horn, 1878, D. minutus (Fabricius, 1775) and D. ocellaris Stephens, 1830
(Coleoptera: Bostrichidae) infesting bamboo stems of Dendrocalamus strictus (Roxb.) Nees (NIXON, 1943), but this species was also observed to live on the grubs of the cotton stem weevil Pempherulus affinis (Faust) and Hypolixus truncatulus (Fabricius) (Coleoptera, Curculionidae) under laboratory conditions (NIXON, 1943). S. vulnificus species was obtained for the first time from the lesser auger beetle in Israel (HALPERIN, 1986).

Our finding represents an interesting updating on the distribution of this wasp. Despite $H$. aequalis has still not established in Italy, $S$. vulnivicus could easily find other bostrichid hosts due to its capability to adapt to other species, affecting the biodiversity of indigenous communities. The role of exotic parasitoids in a new habitat is controversial and debated from long time as the establishment of an exotic species may alter food webs at different trophic levels (BENNET, 1993; KONOPKA et al., 2016). Any contribution to the recording of new introduced species can enlarge the knowledge on the potential alterations of ecological relationships among native and exotic species and allow to perform a meta-analysis of the cumulated data across time.

\section{ACKNOWLEDGMENTS}

This work was supported by the grant of the University of Milan "Exotic pests in a changing world: detection and management - EXPAND".

\section{REFERENCES}

Azmi M., Aвоо F., Razi N., 2011 - World Distribution of Heterobostrychus aequalis Waterhouse (Coleoptera: Bostrychidae). - Journal of Entomology, 8: 497-511.

Baranchikov Y, Mozolevskaya E, Yurchenko G, Kenis M., 2008 - Occurrence of the emerald ash borer, Agrilus planipennis in Russia and its potential impact on European forestry. - Bulletin OEPP/EPPO Bulletin, 38: 233-238.

Belokobylskij S.A., 1996a - A contribution to the knowledge of the Doryctinae of Taiwan (Hymenoptera: Braconidae). - Zoosystematica Rossica, 5: 154-191.

BelokobylskiJ S.A., 1996b - Parasitism on the beetles (Coleoptera) as important stage in the evolution of Braconids wasps (Hymenoptera, Braconidae). Entomologicheskoe Obozrenie. 75(3): 660-676 (in Russian).

Belokobylskis S.A., 2003 - The species of the Genus Spathius Nees, 1818 (Hymenoptera: Doryctinae) not included in the monography by Nixon (1943). - Annales Zoologici, 53: 347-488.

BELOKOBYLSKIJ S.A., 2009 - New species of the braconide wasps of the genus Spathius Nees (Hymenoptera, Braconidae, Doryctinae) from Japan and neighbouring territories. Entomologicheskoe Obozrenie, 88: 438-465.

Belokobylskij S., Maeto K., 2009 - Doryctinae (Hymenoptera: Braconidae) of Japan. Natura optima dux Foundation, Warszawa, Poland: $866 \mathrm{pp}$.

BENNET, F. D., 1993 - Do introduced parasitoids displace native ones? - Florida Entomologist, 76: 54-63.

BERRY J.A., WALKER G.P., 2004 - Meteorus pulchricornis (Wesmael) (Hymenoptera: Braconidae: Euphorinae): an exotic polyphagous parasitoid in New Zealand. - New Zealand Journal of Zoology, 31: 33-44.

Bradshaw C.J.A, Leroy B., Bellard C., Roiz D., Albert 


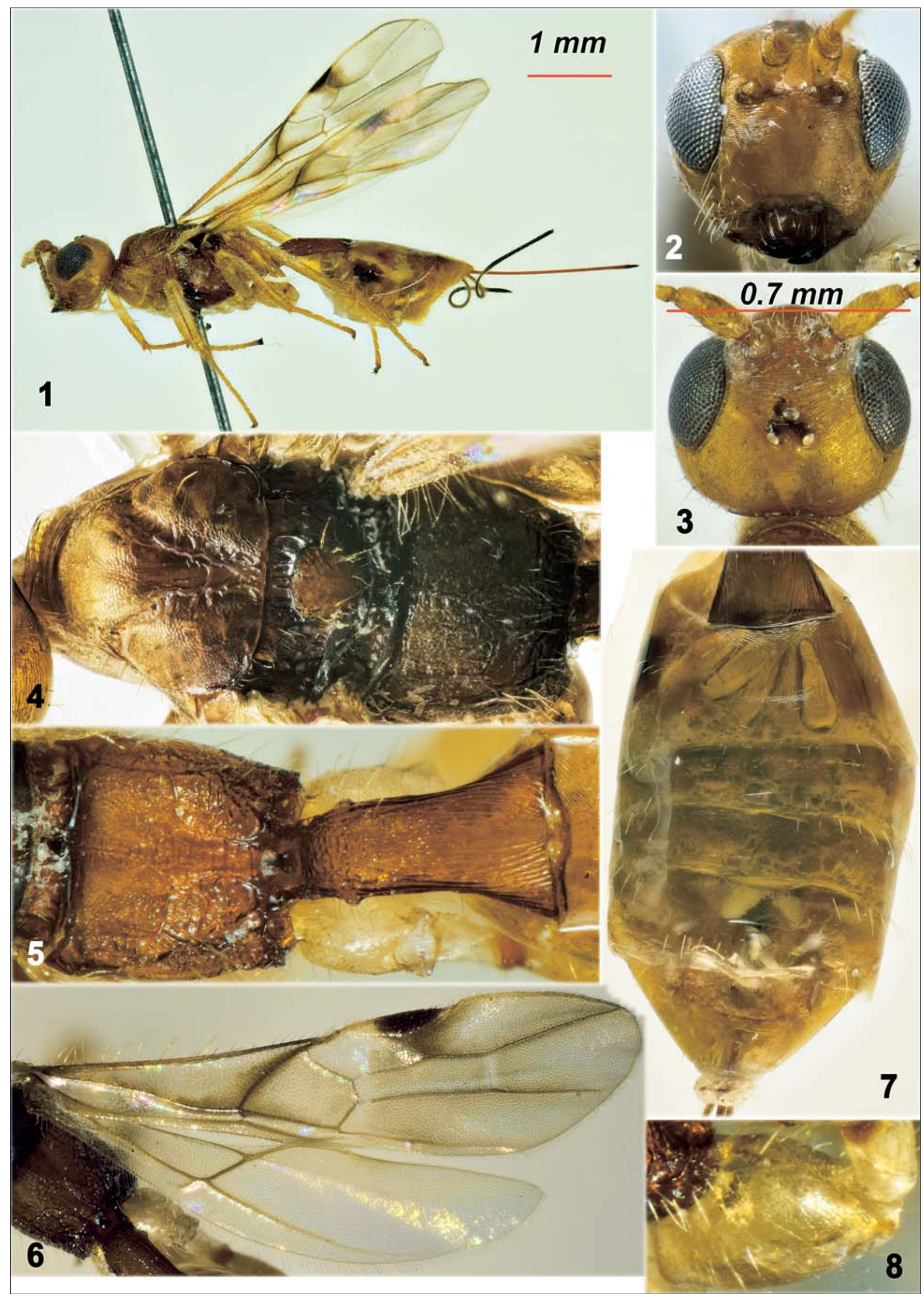

Fig. I - Spathius vulnificus Wilkinson (Italy). 1 - habitus, lateral view; 2 - head, front view; 3 - head, dorsal view; 4 - mesosoma, dorsal view; 5 - propodeum and petiole, dorsal view; 6 - wings; 7 - metasoma (without petiole), dorsal view; 8 - hind coxa, lateral view. 
C., Fournier A., Barbet-Massin M., SAlles J.M., Simard F., Courchamp, F., 2016 - Massive yet grossly underestimated global costs of invasive insects. - Nature communications, 7: 12986.

Faccoli M., Favaro R., Smith M. T., Wu J., 2015 - Life history of the Asian longhorn beetle Anoplophora glabripennis (Coleoptera Cerambycidae) in southern Europe. - Agricultural and forest entomology, 17: 188196.

HALPERIN J., 1986 - Braconidae (Hymenoptera) associated with forest and ornamental trees and shrubs in Israel. Phytoparasitica, 14: 119-135.

Humble L., 2010 - Pest risk analysis and invasion pathways-insects and wood packing revisited: What have we learned. - New Zealand Journal of Forestry Science, 40 Suppl.

JUCKer C., LuPI D., 2011 - Exotic Insects in Italy: An Overview on Their Environmental Impact. In: The Importance of Biological Interactions in the Study of Biodiversity, Jordi Lopez Pujol (Ed.), InTech: 51-74.

KAUFMAN L. V., WRIGHT M. G., 2009 - The impact of exotic parasitoids on populations of a native Hawaiian moth assessed using life table studies. - Oecologia, 159: 295 304.

Konopka J. K., Haye T., Gariepy T., Mason P., Gillespie D., McNeIL J. N., 2016 - An exotic parasitoid provides an invasional lifeline for native parasitoids. - Ecology and evolution, 7: 277-284.

LONI A., HART R.S., LuCCHI A., 2012 - First record of Zombrus bicolor (Enderlein) (Hymenoptera,Braconidae, Doryctinae) in Western Europe. - ZooKeys, 219: 87-91.

Loni A., Jucker C., BelokobylskiJ S., Lupi D., 2015 First record of Rhoptrocentrus piceus Marshall (Hymenoptera, Braconidae, Doryctinae) as parasitoid of Psacothea hilaris hilaris (Pascoe) (Coleoptera, Cerambycidae). - ZooKeys, 482: 1-8.

Lupi D., Jucker C., COlOMBo M., 2013 - Distribution and biology of the yellow-spotted longicorn beetle Psacothea hilaris hilaris (Pascoe) in Italy. - OEPP/ EPPO Bulletin, 43: 316-322.

MacLeod A., Hugh F. E., BAKER Richard H.A., $2002-A n$ analysis of pest risk from an Asian longhorn beetle (Anoplophora glabripennis) to hardwood trees in the European community. - Crop Protection, 21: 635-645.

MASPERo M., JuCKer C., COLOMBO M., 2007 - First record of Anoplophora glabripennis (Motschulsky) (Coleoptera
Cerambycidae Lamiinae Lamiini) in Italy. - Bollettino di Zoologia agraria e di Bachicoltura, 37: 161-164.

NIXON G.E.J., 1943 - A revision of the Spathiinae of the old world (Hymenoptera, Braconidae). - Transaction of the royal entomological Society of London, 93: 173-456.

Pimentel D., Zuniga R., Morrison D., 2005 - Update on the environmental and economic costs associated with alien-invasive species in the United States. - Ecological economics, 52: 273-288.

Poland T.M., McCullough D.G., 2006 - Emerald ash borer: invasion of the urban forest and the threat to North America's ash resource. - Journal of Forestry, 104:118124.

Roques A., Rabitsch W., Rasplus J.Y., Lopez-VAamonde C., Nentwig W., Kenis, M., 2009 - Alien terrestrial invertebrates of Europe. In: The Handbook of Alien Species in Europe. Springer eds., Heidelberg, Germany: 63-79.

RoQues A., 2010 - Alien forest insects in a warmer world and a globalised economy: impacts of changes in trade, tourism and climate on forest biosecurity. - New Zealand Journal of Forestry Science, 40. Suppl.

Shenefelt R.D., MARSh P.M., 1976 - Hymenopterorum Catalogus. Pars 13. Braconidae 9. Doryctinae. 's Gravenhage: Dr W. Junk. pp. 1263-1424.

TAng P., Belokobylskiu S.A., Chen X.X., 2015 - Spathius Nees, 1818 (Hymenoptera: Braconidae: Doryctinae) from China with a key to species. - Zootaxa. Monograph, 3960 (1): 1-132.

WiLKInson D.S., 1931 - On the Indo-Australian and Ethiopian species of the braconid Genus Spathius (Hymenoptera). - Transaction of the royal entomological Society of London, 79: 505-530.

Yu, D.S., Van Achterberg C., Horstmann K., 2016 Taxapad 2016. Ichneumonoidea 2015 (Biological and taxonomical information), Taxapad Interactive Catalogue Database on flash-drive. Nepean, Ottawa (2016) Available at: http://www.taxapad.com [Data accessed: October 16, 2018]

Zaldívar-Riverón A., BeloKobylskij S.A., MeZa-LÁzaro R., Pedraza-Lara C., García-París M., Meseguer A.S., 2018 - Species delimitation, global phylogeny and historical biogeography of the parasitoid wasp genus Spathius (Braconidae: Doryctinae) reveal multiple Oligocene-Miocene intercontinental dispersal events. Zoological Journal of the Linnean Society,182: 723-734. 